\title{
Kepraktisan Aplikasi Fisika Isomorfis (FORFIS) Berbasis Android dalam Menunjang Pembelajaran Mandiri
}

\author{
Desy Kumala Sari ${ }^{*}$ \\ ${ }^{1}$ Jurusan Pendidikan Fisika, Universitas Musamus, Merauke, Indonesia \\ *e-mail korespondensi: sari_fkip@unmus.ac.id \\ (masuk: 12-05-2020; revisi: 30-05-2020; diterima: 04-06-2020)
}

\begin{abstract}
Abstrak: Aplikasi Fisika Isomorfis (FORFIS) merupakan aplikasi berbasis Android yang dapat melatih peserta didik untuk memecahkan masalah-masalah yang bersifat Isomorfis. Konten aplikasi ini telah ditelaah oleh ahli dan telah dinyatakan "layak". Namun, kepraktisan aplikasi FORFIS dalam pembelajaran fisika di kelas belum dilakukan pengujian. Oleh karena itu, tujuan penelitian ini adalah untuk mengetahui kepraktisan aplikasi FORFIS dalam pembelajaran fisika di dalam kelas. Jenis penelitian ini adalah penelitian deskriptif. Data diperoleh melalui angket respon peserta didik setelah proses pembelajaran. Data dianalisis menggunakan teknik analisis deskriptif kuantitatif dalam bentuk persentase. Hasil persentase kemudian diinterpretasikan sesuai dengan kriteria kepraktisan. Analisis data menunjukkan rata-rata respon peserta didik sebesar $92 \%$ dengan kategori "sangat baik". Hal ini berarti peserta didik sangat tertarik pada aplikasi FORFIS. Dengan demikian, aplikasi FORFIS merupakan aplikasi pembelajaran mandiri yang telah layak dan praktis digunakan dalam memenuhi sumber belajar peserta didik.
\end{abstract}

Kata kunci: Android, aplikasi fisika isomorfis (FORFIS), kepraktisan

\section{PENDAHULUAN}

Era revolusi industri 4.0 menambah daftar panjang tantangan pendidikan di abad ke-21. Pendidikan memiliki tujuan untuk mempersiapkan sumber daya manusia yang berkompeten dalam tiga dimensi yakni dimensi sikap, pengetahuan, dan keterampilan. UNESCO merekomendasikan 4 pilar pendidikan untuk menghadapi realita pendidikan saat ini (Delors dkk., 1996). Pilar-pilar yang dimaksud adalah learning to know, learning to do, learning to live together, dan learning to be. Penerapan kurikulum 2013 juga merupakan salah satu solusi yang diberikan pemerintah di Indonesia untuk menjawab tantangan pendidikan di abad ini.

Pengembangan kurikulum 2013 di Indonesia disesuaikan dengan kebutuhan dan kesiapan peserta didik untuk menghadapi realita di masa depan. Selain itu, alternatif yang potensial digunakan dengan tujuan untuk membangun kompetensi di abad XXI adalah dengan menggunakan pendekatan Science, Technology, Engineering, and Mathematics dalam pembelajaran (Permanasari, 2016). Pendidikan saat ini sebaiknya juga diorientasikan pada matematika dan sains (BSNP, 2010).

Fisika sebagai cabang ilmu sains memiliki tujuan untuk melatih kemampuan pemecahan masalah (Docktor \& Mestre, 2014; Gerace \& Beatty, 2005). Kemampuan memecahkan suatu masalah merupakan hasil belajar yang paling penting (Jonassen, 2010). Pentingnya kemampuan pemecahan masalah ini memiliki potensi untuk dikembangkan.

Perkembangan teknologi di abad XXI yang semakin pesat juga membawa tantangan sendiri dalam dunia pendidikan (BSNP, 2010). Pesatnya perkembangan 
teknologi di abad XXI berpotensi untuk dimanfaatkan dalam dunia pendidikan. Bentuk pengembangan teknologi dalam dunia pendidikan disebut E-Learning (Muzyanah, Asmaningrum, \& Buyang, 2018). Produk teknologi yang paling populer di kalangan masyarakat saat ini adalah smartphone. Berdasarkan survei APJII tahun 2018 diperoleh informasi bahwa di Indonesia, pengguna smartphone berbasis Android sebanyak 88\% (Asosiasi Penyelenggara Jasa Internet Indonesia, 2018). Selain itu, hasil survei APJII juga memberikan informasi terkait alasan penggunaan internet oleh masyarakat. Alasan masyarakat menggunakan internet setiap harinya adalah untuk media sosial sebanyak 19.1\%, komunikasi sebanyak $16.7 \%$ dan mengisi waktu luang sebanyak 15.2\% (Asosiasi Penyelenggara Jasa Internet Indonesia, 2018). Data ini menunjukkan bahwa pemanfaatan smartphone yang berbasis Android di Indonesia belum secara maksimal digunakan sebagai media untuk belajar. Kemampuan peserta didik dalam bidang teknologi masih cukup rendah (Supriyadi, Bahri, \& Waremra, 2018). Faktor penyebabnya adalah kurangnya penggunaan media pembelajaran fisika berbasis teknologi. Hal ini menunjukkan perlu ada usaha dari pendidik untuk memaksimalkan pemanfaatan smartphone berbasis Android sebagai media pembelajaran di sekolah.

Penggunaan media pembelajaran berbasis Android dalam suatu pembelajaran merupakan salah satu gaya belajar di abad XXI (Calimag, Miguel, Conde, \& Aquino, 2014). Hasil penelitian Hanafi \& Samsudin menunjukkan bahwa smartphone berbasis Android memberikan keunggulan berupa kemampuan interaktif, akses serta kesenangan sehingga peserta didik menyukai penggunaannya (Hanafi \& Samsudin, 2012). Selain itu, smartphone dalam pembelajaran dalam hal ini pada mata pelajaran fisika memberi kemudahan bagi peserta didik sehingga peserta didik dapat belajar kapan saja dan dimana saja (González dkk., 2015). Manfaat penggunaan media pembelajaran berbasis
Android sangat menguntungkan, maka perlu dikembangkan suatu media pembelajaran berbasis Android khususnya pada mata pelajaran fisika.

Aplikasi Fisika Isomorfis (FORFIS) merupakan salah satu media pembelajaran yang dapat dimanfaatkan dalam mata pelajaran fisika. Aplikasi ini dapat dimanfaatkan dengan bantuan smartphone berbasis Android. Kemampuan yang dapat dilatih menggunakan aplikasi ini adalah kemampuan transfer analogi (Sari, Supahar, \& Ralmugiz, 2018) yang merupakan salah satu aspek dari pemecahan masalah. Suatu media pembelajaran dikatakan berkualitas dan baik digunakan jika memenuhi tiga persyaratan yakni uji kelayakan, uji kepraktisan dan uji keefektifan (Nieveen, 1999). Konten yang dimuat dalam aplikasi ini berupa instrumen penilaian juga telah ditelaah oleh ahli dan dinyatakan layak untuk digunakan (Sari \& Supahar, 2018). Aplikasi FORFIS disajikan pada Gambar 1.
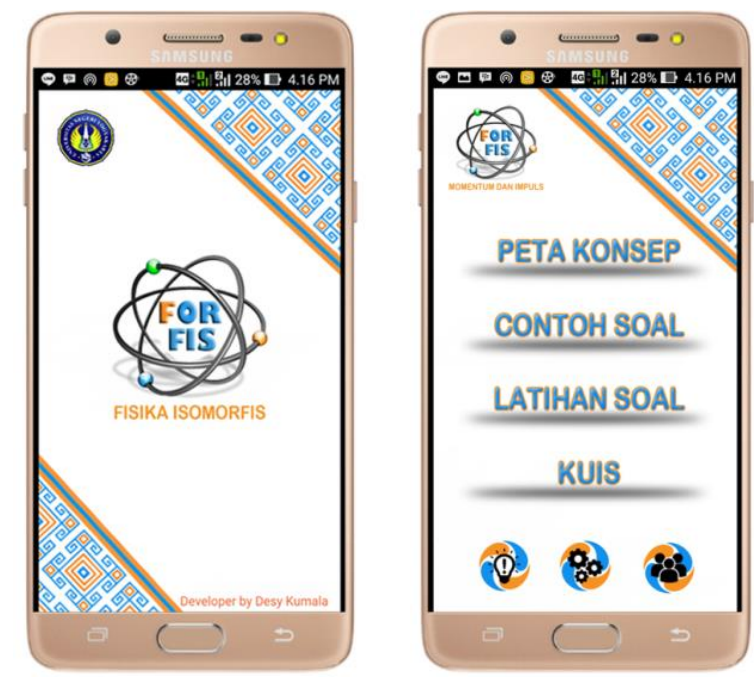

\section{Gambar 1. Tampilan Aplikasi FORFIS}

Tulisan ini merupakan lanjutan pengujian aplikasi FORFIS dalam suatu pembelajaran. Hasilnya berupa respon peserta didik setelah menggunakan aplikasi FORFIS dalam pembelajaran. Respon merupakan suatu rangsangan yang diberikan dengan tujuan agar terjadi perubahan sikap (Asmaningrum, Khoe, \& Sukirno, 2018). Penelitian ini bertujuan 
untuk mengetahui kepraktisan aplikasi FORFIS dalam pembelajaran fisika di kelas.

\section{METODE PENELITIAN}

Penelitian ini termasuk kedalam penelitian deskriptif yang bertujuan untuk menganalisis dan mendeskripsikan respon penggunaan aplikasi FORFIS dalam pembelajaran fisika. Responden dalam penelitian ini adalah peserta didik kelas $\mathrm{X}$ MIPA 5 SMA Negeri 6 Yogyakarta.

Data penelitian diperoleh dari angket respon peserta didik. Angket diberikan setelah pembelajaran berakhir (Arikunto, 2010). Data hasil penelitian kemudian dianalisis menggunakan teknik analisis deskriptif kuantitatif melalui persentase hasil yang diperoleh. Hasil persentase yang diperoleh diinterpretasikan sesuai dengan kriteria kepraktisan (Riduwan, 2005) yang disajikan pada Tabel 1.

Tabel 1. Kriteria Kepraktisan

\begin{tabular}{ccc}
\hline $\begin{array}{c}\text { Persentase } \\
(\%)\end{array}$ & Kategori & Singkatan \\
\hline $81-100 \%$ & Sangat baik & SB \\
$61-80 \%$ & Baik & B \\
$41-60 \%$ & Cukup Baik & $\mathrm{C}$ \\
$21-40 \%$ & Kurang Baik & $\mathrm{K}$ \\
$0-20 \%$ & Tidak Baik & $\mathrm{T}$ \\
\hline
\end{tabular}

Aplikasi FORFIS dikatakan layak jika persentase hasil respon peserta didik berada pada kategori "Sangat Baik" dan "Baik". Aplikasi FORFIS dikatakan praktis digunakan dalam pembelajaran apabila rata-rata respon peserta didik $\geq 61 \%$ dari skor kriteria.

\section{HASIL DAN PEMBAHASAN}

Angket respon peserta didik diberikan setelah seluruh kegiatan pembelajaran selesai. Tujuannya untuk mengetahui respon peserta didik setelah menggunakan aplikasi FORFIS serta ketertarikan peserta didik terhadap aplikasi FORFIS. Data hasil respon peserta didik setelah menggunakan aplikasi FORFIS dalam pembelajaran disajikan pada Tabel 2 .
Tabel 2. Persentase Hasil Respon

Terhadap Penggunaan Aplikasi FORFIS

\begin{tabular}{clcc}
\hline No & \multicolumn{1}{c}{ Pernyataan } & (\%) & Kategori \\
\hline 1. & Soal-soal dalam & 100 & SB \\
& aplikasi FORFIS & & \\
& sesuai dengan & & \\
& perkembangan & & \\
& ilmu dan juga \\
& teknologi saat ini & & \\
& &
\end{tabular}

2. Warna background aplikasi FORFIS sesuai dengan tulisan dan gambar

\begin{tabular}{|c|c|c|}
\hline $\begin{array}{ll}\text { 3. } & \text { Tulisan pada } \\
\text { aplikasi FORFIS } \\
\text { sesuai dengan } \\
\text { gambar }\end{array}$ & 86.67 & SB \\
\hline
\end{tabular}

\begin{tabular}{lll} 
4. $\begin{array}{l}\text { Ukuran huruf pada } \\
\text { aplikasi FORFIS } \\
\text { sesuai dan dapat } \\
\text { dibaca }\end{array}$ & & B \\
\hline
\end{tabular}

5. Ukuran gambar $93.33 \quad$ SB pada aplikasi

FORFIS sesuai dan dapat dibaca

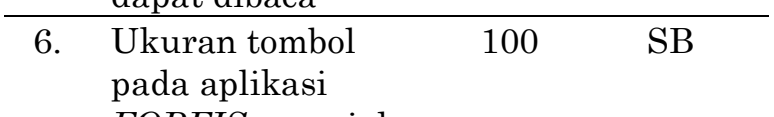
FORFIS sesuai dan dapat dioperasikan

7. Posisi tombol pada $100 \quad$ SB aplikasi FORFIS

tidak berpindah dan tidak membingungkan

\begin{tabular}{|c|c|c|c|}
\hline 8. & $\begin{array}{l}\text { Aplikasi FORFIS } \\
\text { dapat dioperasikan } \\
\text { dengan mudah }\end{array}$ & 93.33 & SB \\
\hline 9. & $\begin{array}{l}\text { Petunjuk } \\
\text { penggunaan } \\
\text { aplikasi FORFIS } \\
\text { disajikan dengan } \\
\text { jelas dan mudah } \\
\text { dipahami }\end{array}$ & 100 & SB \\
\hline 10 & $\begin{array}{l}\text { Penyajian soal-soal } \\
\text { dalam aplikasi } \\
\text { FORFIS } \\
\text { membantu dalam } \\
\text { mengasah } \\
\text { kemampuan } \\
\text { menyelesaikan } \\
\text { masalah }\end{array}$ & 86.67 & SB \\
\hline
\end{tabular}

Berdasarkan hasil analisis data penelitian, diperoleh rata-rata respon peserta didik setelah menggunakan aplikasi FORFIS dalam pembelajaran 
fisika sebesar 92\%. Sesuai dengan kriteria kepraktisan pada Tabel 1, persentase respon peserta didik berada pada kategori "Sangat Baik". Faktor-faktor yang menyebabkan respon peserta didik yang sangat baik ini adalah, tampilan aplikasi FORFIS sangat menarik, penggunaannya tidak membingungkan, dipermudah dengan adanya petunjuk penggunaan, dan membantu dalam menyelesaikan masalah. Menarik atau tidaknya suatu media pembelajaran bergantung pada tampilan yang digunakan. Peserta didik zaman sekarang sudah lebih kreatif dan minat terhadap seni cukup beragam oleh karena itu tampilan suatu media pembelajaran harus disesuaikan dengan kebutuhan peserta didiknya.

Pada dasarnya penggunaan aplikasi FORFIS oleh peserta didik menunjukkan respon yang positif. Aplikasi ini dinilai oleh peserta didik dapat membantu dalam menyelesaikan soal-soal terutama pada materi momentum dan impuls. Respon positif peserta didik terhadap media pembelajaran ini perlu menjadi perhatian penting bagi peneliti. Aplikasi FORFIS mampu untuk membantu peserta didik dalam mengikuti pembelajaran secara mandiri. Basis aplikasi FORFIS berupa Android ini cukup memudahkan dan membantu dalam pembelajaran. Bagaimana tidak, aplikasi FORFIS ini termasuk media pembelajaran berbasis Android yang mana merupakan salah satu gaya belajar abad ke-21 (Calimag dkk., 2014). Hal ini merupakan potensi yang perlu di kembangkan dalam menunjang pembelajaran peserta didik baik secara mandiri maupun di dalam kelas.

Selanjutnya, data hasil respon peserta didik terhadap ketertarikan pada aplikasi FORFIS sebagai media dalam pembelajaran di dalam kelas disajikan pada Tabel 3. Data diperoleh dari angket yang diberikan setelah pembelajaran selesai.

Tabel 3. Hasil Respon Terhadap Ketertarikan Peserta Didik Pada Aplikasi FORFIS

\begin{tabular}{cccc}
\hline No & Pernyataan & (\%) & Kategori \\
\hline 1. & $\begin{array}{l}\text { Aplikasi FORFIS } \\
\text { dapat }\end{array}$ & 93.33 & SB \\
\hline
\end{tabular}

\begin{tabular}{|c|c|c|c|}
\hline No & Pernyataan & $(\%)$ & Kategori \\
\hline & $\begin{array}{l}\text { memotivasi } \\
\text { dalam belajar } \\
\text { materi } \\
\text { Momentum dan } \\
\text { Impuls }\end{array}$ & & \\
\hline 2. & $\begin{array}{l}\text { Aplikasi FORFIS } \\
\text { dapat } \\
\text { memudahkan } \\
\text { dalam belajar } \\
\text { secara mandiri }\end{array}$ & 100 & SB \\
\hline 3. & $\begin{array}{l}\text { Aplikasi FORFIS } \\
\text { dapat dibawa ke } \\
\text { mana saja } \\
\text { sehingga saya } \\
\text { dapat belajar } \\
\text { kapan saja } \\
\end{array}$ & 100 & SB \\
\hline 4. & $\begin{array}{l}\text { Soal-soal yang } \\
\text { dimuat pada } \\
\text { aplikasi FORFIS } \\
\text { menarik untuk } \\
\text { dipelajari } \\
\end{array}$ & 86.67 & $\mathrm{SB}$ \\
\hline 5. & $\begin{array}{l}\text { Soal-soal yang } \\
\text { dimuat pada } \\
\text { aplikasi FORFIS } \\
\text { membantu saya } \\
\text { menyelesaikan } \\
\text { soal-soal di buku }\end{array}$ & 93.33 & SB \\
\hline & Rata-rata & 94.66 & SB \\
\hline
\end{tabular}

Rata-rata hasil respon terhadap ketertarikan peserta didik pada aplikasi FORFIS adalah 94.66\%. Sesuai dengan kriteria kepraktisan pada Tabel 1, maka ketertarikan peserta didik terhadap aplikasi FORFIS "Sangat Baik". Artinya peserta didik sangat tertarik dengan aplikasi FORFIS untuk pembelajaran baik di dalam kelas maupun secara mandiri. Penggunaan aplikasi FORFIS dalam pembelajaran dapat memotivasi peserta didik dalam belajar, dan memudahkan untuk belajar kapan saja dan dimana saja. Media pembelajaran berbasis Android ini menawarkan kesenangan bagi peserta didik (Hanafi \& Samsudin, 2012). Hal ini dikarenakan pemanfaatan potensi yang ada pada peserta didik berupa pengguna smartphone. Kehidupan masyarakat termasuk peserta didik tidak terlepas dari penggunaan smartphone. Oleh karena itu potensi yang ada ini dapat membantu dalam pembelajaran mandiri maupun di sekolah. 
Ketertarikan peserta didik terhadap aplikasi FORFIS mendapat respon yang positif juga. Hal ini menunjukkan bahwa aplikasi jenis ini mampu menarik perhatian peserta didik dalam pembelajaran. Ketertarikan merupakan bagian yang cukup penting untuk menarik perhatian peserta didik sehingga paling tidak setelah peserta didik tertarik terhadap media pembelajaran tertentu, diharapkan peserta didik dapat termotivasi dalam mengikuti pembelajaran.

\section{SIMPULAN}

Sesuai dengan hasil data respon peserta didik terhadap penggunaan dan ketertarikan pada aplikasi FORFIS disimpulkan bahwa aplikasi FORFIS memiliki tingkat kepraktisan yang 'sangat baik'. Hal ini berarti peserta didik memberikan respon yang positif untuk menggunakan aplikasi FORFIS dalam pembelajaran. Ketertarikan peserta didik terhadap aplikasi FORFIS dalam pembelajaran juga berada pada kategori 'sangat baik' yang berarti bahwa peserta didik sangat tertarik pada aplikasi FORFIS. Dengan demikian aplikasi FORFIS dinyatakan praktis digunakan dalam pembelajaran fisika materi momentum dan impuls baik di dalam kelas maupun dalam pembelajaran mandiri.

\section{REFERENSI}

Arikunto, S. (2010). Dasar-dasar Evaluasi Pendidikan. Jakarta: PT. Bumi Aksara.

Asmaningrum, H. P., Khoe, R. I., \& Sukirno. (2018). Analisis Respon Siswa Terhadap pengembangan Buku Suplemen Kimia Berbasis Kearifan Lokal Suku Asmat Papua. Musamus Journal of Science Education, 1(1), 2126.

Asosiasi Penyelenggara Jasa Internet Indonesia, A. (2018). Penetrasi \& profil perilaku pengguna internet indonesia (Survei 2018).

BSNP. (2010). Paradigma pendidikan nasional abad xxi. Indonesia.

Calimag, J. A. N. N. V, Miguel, P. A. G.,
Conde, R. S., \& Aquino, L. B. (2014). Ubiquitos learning environment using Android mobile application. IMPACT: International Journal of Research in Engineering \& Technology, 2(2), 119128.

Delors, J., Chairman, Mufti, I. Al, Amagi, I., Carneiro, R., Chung, F., ... Nanzhao, Z. (1996). Learning: the treasure within. UNESCO PUBLISHING.

Docktor, J. L., \& Mestre, J. P. (2014). Synthesis of discipline-based education research in physics. Physics Education Research, 020119(10), 1-58. https://doi.org/10.1103/PhysRevSTPE R.10.020119

Gerace, W. J., \& Beatty, I. D. (2005). Teaching vs . Learning: changing perspectives on problem solving in ihysics instruction. In 9th Common Conference of the Cyprus Physics Association and Greek Physics Association (pp. 1-10). Retrieved from https://journals.aps.org/prper/abstract /10.1103/PhysRevSTPER.10.020119\% $0 \mathrm{~A} \% 0 \mathrm{~A} \% 0 \mathrm{~A}$

González, M. Á., González, M. Á., Martín, M. E., Llamas, C., Martínez, Ó., Vegas, J., ... Hernández, C. (2015). Teaching and Learning Physics with Smartphones. Journal of Cases on Information Technology, 17(1), 31-50. https://doi.org/10.4018/JCIT.20150101 03

Hanafi, H. F., \& Samsudin, K. (2012). Mobile learning environment system ( MLES ): The case of Android-based learning application on undergraduates , learning. International Journal of Advanced Computer Science and Applications, 3(3), 1-5. https://doi.org/10.14569/IJACSA.2012. 030311

Jonassen, D. H. (2010). Research Issues in Problem Solving. In The 11th International Conference on Education Research (pp. 1-15).

Muzyanah, S., Asmaningrum, H. P., \& Buyang, Y. (2018). Efektivitas Penggunaan Media Edmodo Sebagai 
Penunjang Pembelajaran Kimia. Musamus Journal of Science Education, 1(1), 33-45.

Nieveen, N. (1999). Prototyping to Reach Product Quality. In J. van den Akker, R. M. Branch, K. Gustafson, N. Nieveen, \& T. Plomp (Eds.), Design Approaches and Tools in Education and Training (p. 296). SpringerScience+Businnes Media, B.V. https://doi.org/10.1007/978-94-0114255-7_1.

Permanasari, A. (2016). STEM education: inovasi dalam pembelajaran sains. In Seminar Nasional Pendidikan Sains (pp. 23-34). Indonesia.

Riduwan. (2005). Skala Pengukuran
Variabel-variabel. Bandung: Alfabeth. Sari, D. K., \& Supahar. (2018). The Content Validity of Assessment Instruments to Measure Analogical-Transfer Ability. International Jorunal of Sciences: Basic and Applied Research, 39(2), 165-172.

Sari, D. K., Supahar, \& Ralmugiz, U. (2018). The Influence of AndroidBased Isomorphic Physics (FORFIS) Application on Analogical Transfer and Self-Diagnosis Skill of Students at SMA Negeri 3 Kupang. Jurnal Pendidikan IPA Indonesia, 7(2), 154161.

https://doi.org/10.15294/jpii.v7i2.1426 8. 